\title{
Incidence of ciguatoxin fish poisoning in Trivandrum, India
}

\author{
R. RAJISHA ${ }^{1}$, PANKAJ KISHORE ${ }^{1}$, SATYEN KUMAR PANDA ${ }^{1}$, G. HARIKRISHNAN ${ }^{2}$, \\ K. C. AJITHA ${ }^{2}$, M. K. SURESH ${ }^{2}$, LABRECHAI MOG CHOWDHURY ${ }^{3}$, C. N. RAVISHANKAR ${ }^{1}$ \\ AND K. ASHOK KUMAR ${ }^{1}$ \\ ${ }^{1}$ ICAR-Central Institute of Fisheries Technology, Matsyapuri P. O., Kochi - 682 029, Kerala, India \\ ${ }^{2}$ Government Medical College, Thiruvananthapuram - 695011, Kerala, India \\ ${ }^{3}$ Peninsular and Marine Fish Genetic Resources Centre of ICAR-National Bureau of Fish Genetic Resources \\ Kochi - 682018, Kerala, India \\ e-mail: rajisharavindran@gmail.com
}

\begin{abstract}
Ciguatoxin (CTX) is a visibly unidentifiable, colourless, odourless, heat stable and lipid soluble polyether marine biotoxin associated with human illness. Marine dinoflagellates under the genus Gambierdiscus are responsible for producing ciguatoxins (CTX). The ciguatoxin gets accumulated in herbivorous fishes, gets biotransformed in carnivorous fishes and finally reach fish consumers. In January 2016, individuals who consumed red snapper in Trivandrum, Kerala, India were suspected to be intoxicated with ciguatera based on characteristic symptoms as assessed by medical team from Trivandrum Medical College, Kerala, India. The red snapper species was identified and confirmed as Lutjanus bohar by DNA barcoding. Mouse bioassay was carried out to detect the presence of ciguatoxin and the tested mice showed symptoms related to suspected CTX toxicity. Significantly higher level of ciguatoxin lethal dose was estimated which was found equivalent to $16.25 \mathrm{ng}$ of CTX-1 which led to $13 \%$ of weight loss in tested mice. Medical professionals also investigated clinical manifestations of suspected toxicity in hospitalised individuals. This study indicated that there is a need for regular surveillance of seafood landed across the coast and consumer's awareness for their safety.
\end{abstract}

Keywords: Ciguatera fish poisoning, Ciguatoxin, Lutjanus bohar, Mouse bioassay

Ciguatoxin (CTX) affects approximately 50,000 to 500,000 people per year (Meyer et al., 2015). Ciguatera fish poisoning (CFP) causes acute gastrointestinal and neurological symptoms, including vomiting, diarrhoea, abdominal pain, severe localised itching, tingling of extremities and lips, dysesthesia, as well as other chronic symptoms (Lewis, 2001; 2006). CFP occurs due to consumption of reef fishes of larger size in tropical and subtropical regions. More than 400 fish species are reported to be causative agents for ciguatera poisoning. Larger fishes accumulate gambiertoxins and their biotransformation in the fish makes it more potent in comparison to those in small fishes (Lehane and Lewis, 2000; Farrell et al., 2016). The dinoflagellate species Gambierdiscus toxicus is the main source of the production of this marine toxin and its accumulation in fishes (FAO, 2004). Ciguatoxin is a colourless, odourless, heat stable and lipid soluble polyether compound. This toxin remains unaffected by freezing, drying or cooking process (Lewis, 2006; Abraham et al., 2011). CTXs are secondary metabolites with numerous congeners having different molecular structure reported from different geographical areas such as Pacific, Caribbean and Indian regions (Caillaud et al., 2010).
Incidence of CTX toxicity from Kerala coast has not been reported so far, as it had escaped many a times the attention of medical practitioners. The present study investigated a recent incident of food poisoning suspected due to ciguatera toxin from red snapper in Trivandrum, which presented characteristic symptoms in those who consumed the fish.

Fish samples for the investigations were collected from Vizhinjam, Kerala, India in January 2016, where intoxication in local population were reported. The poisoning occurred due to the consumption of cooked "red snapper" fish coming under the genus Lutjanus, purchased from the local fish market. Medical team from Trivandrum Medical College observed that the intoxicated persons had consumed same fishes and developed neurological and gastrointestinal complications similar to that of ciguatera fish poisoning. The fish samples collected were stored at $-20^{\circ} \mathrm{C}$ until analysis.

Caudal peduncle samples of the fishes were used for species authentication by sequence analysis of mitochondrial cytochrome c oxidase subunit I (COI) gene. The total genomic DNA from the samples was isolated using DNeasy Blood and Tissue Kit (Qiagen, Germany), 
as per manufacturer's instructions and concentration as well as purity of the extracted DNA was estimated using a biospectrometer (Eppendorf, Germany). The COI gene was amplified using universal primer pair (Ward et al., 2005) (Table 1).

Table 1. Primers used for identification of fish implicated in Ciguatera fish poisoning

\begin{tabular}{ll}
\hline Primer name & Sequence \\
\hline Fish F1 & 5'- TCAACCAACCACAAAGACATTGGCAC -3' \\
Fish R1 & 5'- TAGACTTCTGGGTGGCCAAAGAATCA -3' \\
\hline
\end{tabular}

The reaction was carried out in $25 \mu 1$ volume, containing mixture of $1 \mathrm{x}$ taq buffer, $2.5 \mathrm{mM} \mathrm{MgCl}_{2}$ and $50 \mu \mathrm{M}$ of each primer, $200 \mu \mathrm{M}$ of each dNTP, $0.5 \mathrm{U}$ taq DNA polymerase, $75 \mathrm{ng}$ of template DNA and autoclaved double distilled water to make up the volume to $25 \mu$. The reaction mixture was thermal cycled for 35 cycles of $30 \mathrm{~s}$ at $94^{\circ} \mathrm{C}, 30 \mathrm{~s}$ at $52^{\circ} \mathrm{C}, 45 \mathrm{~s}$ at $72^{\circ} \mathrm{C}$ and final extension of $10 \mathrm{~min}$ at $72^{\circ} \mathrm{C}$, with an initial denaturation step at $95^{\circ} \mathrm{C}$ for $4 \mathrm{~min}$. The PCR products were sequenced bidirectionally using ABI 3730 capillary sequencer in the sequencing facility. The raw DNA sequences obtained were edited and aligned using BioEdit version 7.0.5.2 (Hall, 1999). The edited partial sequences of COI gene were analysed for species identification using the NCBI BLAST search engine and the sequences were submitted to GenBank database (NCBI, USA).

Extraction of ciguatoxin from fish samples was carried out as per IOC manuals and Guides No. 33 (Hallegraeff et al., 1995) and European Union Reference method (ANSES, 2016) for mouse bioassay of ciguatoxin. Fifty gram of fish sample was cooked at $70^{\circ} \mathrm{C}$ for $15 \mathrm{~min}$, and cooled to room temperature. Tissue samples were then minced, diluted with acetone $[3: 1 \mathrm{~V}: \mathrm{W}$ $\left.\left(\mathrm{ml} \mathrm{g}^{-1}\right)\right]$ and homogenised for 5-15 min using a homogeniser (PRO Scientific Inc., USA) under iced condition. The homogenised samples were filtered using Whatman no.1 filter paper and the filtrate collected in a round bottom flask. Residual acetone and water were removed using a rotary evaporator (Heidolph, Germany) operated at $55^{\circ} \mathrm{C}$. The dried extract was transferred to a separatory funnel, added methanol:water (9:1), shaken well followed by extraction with $1: 1(\mathrm{v} / \mathrm{v}) \mathrm{n}$ hexane and the upper hexane layer was discarded. This extraction process was repeated twice. The residual methanol:water was removed using vacuum evaporator. Further, ethanol:water (1:3) was added and shaken with diethyl ether (1:1) to separate the layers and the ether layer was collected. Ether extraction was repeated twice and ether fractions were pooled at an elevated temperature of $40-55^{\circ} \mathrm{C}$. The dried ether extract collected were assumed to contain the CTXs.
Ether extract was dissolved in chloroform:methanol (97:3) mixture and dried under $\mathrm{N}_{2}$. The dried ether fraction was suspended in $1-5 \%$ tween $60 / 0.9 \%$ saline, sonicated for $180 \mathrm{~s}$ and filtered through 0.45 PTFE membrane filter prior to administering into mice.

Female albino mice weighing $20 \pm 2 \mathrm{~g}$ were used for the assay done in duplicate, by intraperitoneal injection with $0.5 \mathrm{ml}$ of the prepared extract, whereas control mice were injected with only $0.5 \mathrm{ml}$ tween $60 /$ saline solution. Details such as time of injection, weight of mice, amount of extract $(\mathrm{g})$ administered, time of onset and nature of signs and time of death were recorded for each injection. The post-injection behaviour was observed and recorded for at least $24 \mathrm{~h}$. Weight loss in injected mice was also recorded at an interval of minimum $3 \mathrm{~h}$ duration.

The symptomatology in the hospitalised patients corroborated with earlier reports of ciguatera fish poisoning (Rajeish et al., 2016) with typical clinical signs like gastrointestinal, neurological and cardiovascular symptoms. All six patients (one male and five females) were admitted with CFP symptoms of vomiting, diarrhoea, paraesthesia of upper limbs and lower limbs. Out of this, five patients belonged to one family comprising husband, wife and three daughters who live near Chakkipara Market, Trivandrum. Their symptoms started six hours after consumption of fish dish (chempalli curry). Symptoms like vomiting, diarrhoea, circumoral paraesthesia and paraesthesia of limbs were common to all family members. One of the three daughters also had paradoxical temperature reversal (cold objects sensed as hot and hot objects sensed as cold). All the patients were haemo-dynamically stable except the husband who had sinus bradycardia (low heart rate). The sixth patient was a female and her major symptom was giddiness. She also had abdominal pain and paraesthesia of limbs. In the affected individuals, the onset of ciguatera toxicity started within $24 \mathrm{~h}$ of consumption of fish curry and symptoms lasted for 1-4 days. However, in case of one individual, it persisted for six months as reported previously by Glaziou and Martin (1993) and Pearn (1995). Clinical diagnoses of CFP are reliable when a detailed and comprehensive history of the food source, onset of the illness and description of symptoms are accounted (Stewart et al., 2009).

All the above said patients were treated by giving supportive measures like intravenous fluids and antiemetics. The husband's bradycardia improved and normal heart rate was restored after 2 days. Patients were in better condition at the time of discharge and the only symptom that persisted was paraesthesia of limbs. 
The partial sequence of the mitochondrial CO1 gene from the tissue samples yielded an average length of $627 \mathrm{bp}$ (Accession. No. KY057337). These sequences were used for identification of species based on the similarity search using the NCBI BLAST search engine and the species was identified as Lutjanus bohar, commonly known as two spot red snapper. L. bohar is a reef-associated tropical fish distributed along the Indo-Pacific region with earlier reports of ciguatera poisoning (Halstead et al., 1990) and large fishes from oceanic areas in the western Pacific are often ciguatoxic (Dalzell, 1992). According to Oshiro et al. (2010), L. bohar weighing less than $4 \mathrm{~kg}$ to be non-toxic and $11.9 \%$ of the species exhibit CTX toxicity.

Intra-peritoneal injection of toxin extract from fish tissue induced symptoms in mice as indicated in case of CTX toxicity. A detailed description of symptoms of toxicity recorded in mice up to a $24 \mathrm{~h}$ period observation is given in Table 2. The prominent symptoms included piloerection, diarrhoea, lachrymation, dyspnoea, gasping, progressive hind limb paralysis, wobbly gait, terminal convulsions with tail arching, breathing difficulties, slow locomotor activity and hypothermia. However, these symptoms were absent when extract from control and negative (non-toxic) fish samples were administered in mice. The relationship between dose and time to death was used to quantify toxicity of the extract which ranged from $30 \mathrm{~min}$ to $>10 \mathrm{~h}$.

Traditional method of detecting the presence of ciguatoxin in fish involves testing lipid extracts by mouse bioassay (Lewis and Sellin,1993) and the most widely used mouse bioassay method was described by Yasumoto et al. (1984) which has been accepted worldwide. The lethal dose i.e., $\mathrm{LD}_{50}$ dose for a $20 \mathrm{~g}$ mouse is equal to one Mouse Unit (MU) which is equivalent to $5 \mathrm{ng}$ CTX-1. One MU is equivalent to $5 \mathrm{ng}, 18 \mathrm{ng}$ and $48 \mathrm{ng}$ for Pacific CTXs, P-CTX-1, P-CTX-2 and P-CTX-3, respectively (Lewis et al., 1991; Lewis and Sellin, 1993) and $72 \mathrm{ng}$ for pure Caribbean CTX-1 (Pottier et al., 2003). Dose and time to death relationship for a mix of ciguatoxins typically found in carnivorous fish is defined according to the equation:

$$
\log M U=2.3 \log (1+1 / \mathrm{T})
$$

where, $\mathrm{T}$ is the time to death in hours (Lewis and Sellin, 1992). The lethal dose was estimated to be $3.25 \mathrm{MU}$ per $20 \mathrm{mg}$ of ether extract and the amount of CTX toxicity in fish sample is equivalent to $16.25 \mathrm{ng}$ of CTX -1, which is significantly higher than the reported levels of CTX intoxication in humans. It was formerly suggested that any fish containing above $2.5 \mathrm{MU}$ $100 \mathrm{~g}^{-1}$ should be avoided as food (Yasumoto et al., 1984) since ciguatoxins are potent neurotoxins that may have long-term neurological effects. The average weight loss observed in the positive sample was calculated as $13 \%$. The evaluation of toxicity of the fish tissue samples based on mouse bioassay was interpreted as shown in Table 3 . The death of 1 or 2 mice within $24 \mathrm{~h}$ is interpreted as positive for ciguatoxicity and the fish sample is rated as inedible. In the absence of death, weight loss $>5 \%$ after $24 \mathrm{~h}$ of injection of atleast one mouse is considered as a positive result for ciguatoxicity and the fish sample is considered as edible to limited extent. When there is no mortality or weight loss, then the sample is edible without doubt. MBA (mouse bioassay) provides a measure of total toxicity based on the biological response of the animal to the toxins but no specific information is provided on individual toxins.

Table 2. Symptoms of ciguatera toxicity recorded during mouse bioassay

\begin{tabular}{llll}
\hline Symptoms & Evaluation & \multicolumn{2}{c}{ Animal responses } \\
\cline { 3 - 4 } & & Control & Toxin treated \\
\hline Hypothermia & Thermometer & $35-38^{\circ} \mathrm{C}$ & Below $33^{0} \mathrm{C}$ \\
Piloerection & Observation & None & Mild to marked \\
Hyper salivation & Observation & Normal & Mild to severe \\
Dyspnoea & Observation & Absent & Mild to severe \\
Wobbly upright gait & Observation & Absent & Mild to severe \\
Gasping & Observation & Absent & Present \\
Withdrawal reflex & Observation & Absent & Mild to marked \\
Mild gasping & Grasp hind leg & Withdrawal & Reduced to absent \\
Diarrhea & Observation & Absent & Present \\
Breathing difficulties & Observation & Absent & Mild \\
Locomotor activity & Observation & Absent & Rapid shallow to intermittent gasping \\
Hind limb paralysis & Observation & Normal & Slow to absent \\
Convulsions & Observation & & Progressive paralysis from hind limb \\
\hline
\end{tabular}


Table 3. Interpretation of ciguatoxicity of fish tissue samples based on mouse bioassay

\begin{tabular}{llll}
\hline Test sample & $\begin{array}{l}\text { No. of dead } \\
\text { mouse (s) in } \\
24 \mathrm{~h}\end{array}$ & $\begin{array}{l}\text { Weight loss } \\
>5 \% \text { after } 24 \mathrm{~h} \\
\text { injection }\end{array}$ & Conclusion \\
\hline $\begin{array}{l}\text { Suspected } \\
\text { sample 1 }\end{array}$ & One of two & Yes & $\begin{array}{l}\text { Positive, } \\
\text { Not edible }\end{array}$ \\
$\begin{array}{l}\text { Suspected } \\
\text { sample 2 }\end{array}$ & 0 & Yes & $\begin{array}{l}\text { Positive, } \\
\text { limited } \\
\text { edibility } \\
\text { Negative, } \\
\text { edible }\end{array}$ \\
\hline
\end{tabular}

Source: EU-NRL (ANSES, 2016)

Banner et al. introduced the MBA for CTXs in 1960 and this is most widely used mammalian in vivo model for toxicity screening of CTXs (Caillaud et al., 2010). Along Indian coast, CFP incidents are infrequent. Routine analysis of samples by mouse bioassay cannot be recommended since it is non-specific and ethically objectionable (Abraham et al., 2011) and considered as a toxicological tool accessible only to selected laboratories. We carried out mouse bioassay test to identify and quantify CTX toxins in order to provide further support for the clinical diagnosis of the CFP incident. Proficiency in the ability to identify the toxic fish and effective clinical recognition will definitely improve our understanding of the source of poisoning.

This study is the first report in incidence of ciguatoxin poisoning along Kerala coast and signifies the importance of seafood safety. In the absence of commercial testing, a precautionary approach is necessary for the surveillance of CTX intoxication along the Indian coast. The implementation of regulatory criteria for CTXs would be needed with respect to aspects like identification of ciguatoxic fish mainly reef associated fish, regulatory measures such as ban or size restrictions on high-risk species and misdiagnosis or under-reporting of CFP cases. A rapid and reliable instrumentation method through mass spectrometry, with the aim of routine monitoring and screening of CFP in reef fishes along the Indian coast is the need of the hour. The study also signifies the need for creating awareness regarding consumption of coral reef fishes and its consequences among the public.

\section{Acknowledgements}

This research is supported in part by Centre for Marine Living Resources and Ecology (Ministry of Earth Sciences) grant. We thank the Director, ICAR-CIFT, Kochi, India for the kind support throughout the work. We also acknowledge Dr. B. Ganeshan for helping us to carry out animal studies.

\section{References}

Abraham, A., Jester, E. L. E., Granade, H. R., Plakas, S. M. and Dickey, R. W. 2011. Caribbean ciguatoxin profile in raw and cooked fish implicated in ciguatera. Food Chem., 131: 192-198.

ANSES 2016. Methoded'analyse en securite sanitaire des aliments: Detection des ciguatoxinesdans la chair de poisson par bioessaisursouris [Method of analysis for food safety: Detection of ciguatoxins in the Flesh by bio-assay on mouse:], ANSES / LSAliments / LSA-INS-0150 - Version 01, 06/04/2016 (French Agency for Food, Environmental and Occupational Health and Safety: Maisons-Alfort, France), $16 \mathrm{pp}$.

Banner, A., Scheuer, P., Sasaki, S., Helfrich, P. and Alender, C 1960. Observations on ciguatera-type toxin in fish. Annals. N. Y. Acad. Sci., 90: 770-787.

Caillaud, A., de la Iglesia, P., Darius, H. T., Pauillac, S., Aligizaki, K., Fraga, S., Chinain M. and Diogene, J. 2010. Update on methodologies available for ciguatoxin determination: Perspectives to confront the onset of Ciguatera fish poisoning in Europe. Marine Drugs, 8(6): 1838-1907. doi:10.3390/md8061838.

Dalzell, P. 1992. Ciguatera fish poisoning and fisheries development in the South Pacific region. Bull. Soc. Pathol. Exot., 85: 435-444.

FAO 2004. Marine biotoxins. FAO food and nutrition paper, Food and Agriculture Organisation of the United Nations, Rome, 80(7): 192 pp.

Farrell, H., Zammit, A., Manning, J., Shadbolt, C., Szabo, L., Harwood, D. T., McNabb, P., Turahui, J. A. and van den Berg D. J. 2016. Clinical diagnosis and chemical confirmation of ciguatera fish poisoning in New South Wales, Australia. Communicable Diseases Intelligence, 40(1): $1-6$

Glaziou, P. and Martin, P. M. 1993. Study of factors that influence the clinical response to ciguatera fish poisoning. Toxicon. 31(9): 1151-1154.

Hall, T. A. 1999. Bioedit: a user-friendly biological sequence alignment editor and analysis program for Windows 95/98/ NT. Nucl. Acids. Symp. Ser., 41: 95-98.

Halstead, B. W., Auerbach, P. S. and Campbell, D. R. 1990 A colour atlas of dangerous marine animals, Wolfe Medical Publications Ltd, W. S. Cowell Ltd., Ipswich, England, $192 \mathrm{pp}$.

Hallegraeff, G. M., Anderson, D. M. and Cembella, A. D. 1995. Manual on harmful marine microalgae, IOC Manuals and Guides No. 33, UNESCO, p. 135-161.

Lehane, L. and Lewis, R. J. 2000. Review Ciguatera: recent advances but the risk remains. Int. J. Food Microbiol., 61: 91-125.

Lewis, R. J. and Sellin, M. 1992. Multiple ciguatoxins in the flesh of fish. Toxicon, 30(8): 915-919. 
Lewis, R. J. 2001. The changing face of ciguatera. Toxicon, 39(1): 97-106.

Lewis, R. J. 2006. Ciguatera: Australian perspectives on a global problem. Toxicon, 48(7): 799-809.

Lewis, R. J. and Sellin, M. 1993. Recovery of ciguatoxin from fish flesh. Toxicon, 31(10): 1333-1336.

Lewis, R .J., Sellin, M., Poli, M. A., Norton, R. S., MacLeod, J. K. and Sheil, M. M. 1991. Purification and characterisation of ciguatoxins from moray eel (Lycodontis javanicus, Muraenidae). Toxicon, 29(9): 1115-1127.

Meyer, L., Carter, S. and Capper, A. 2015. An updated ciguatoxin extraction method and silica cleanup for use with HPLC - MS/MS for the analysis of P-CTX-1, PCT-X-2 and P-CTX-3. Toxicon, 108: 249-256.

Oshiro, N., Yogi, K., Asato, S., Sasaki, T., Tamanaha, K., Hirama, M., Yasumoto, T. and Inafuku, Y. 2010. Ciguatera incidence and fish toxicity in Okinawa, Japan. Toxicon, 56(5): 656-661.

Pearn, J. 1995. Ciguatera - a potent cause of the chronic fatigue syndrome. Int. J. Immunopharmacol., 15: 63-65.
Pottier, I., Hamilton, B., Jones, A., Lewis, R. and Vernoux, J. 2003. Identification of slow and fast-acting toxins in a highly ciguatoxic barracuda (Sphyraena barracuda) by HPLC/MS and radiolabeled ligand binding. Toxicon, 42(6): 663-672.

Rajeish, M., Shekar, M., Madhushree, H. N. and Venugopal, M. N. 2016. Presumptive case of ciguatera fish poisoning in Mangalore, India. Research Communications. Curr. Sci., 111(9): 1543-1547.

Stewart, I., Eaglesham, G., Poole, S., Graham, G., Paulo, C., Wickramasinghe, W., Sadler, R. and Shaw, G. 2009. Establishing a public health analytical service based upon chemical methods for detecting and quantifying Pacific ciguatoxin in fish samples. Toxicon, 56(5): 804-812.

Yasumoto, T., Raj, U. and Bagnis, R. 1984. Seafood poisonings in tropical regions, Laboratory of Food Hygiene, Faculty of Agriculture, Tohoku University, Japan, 74 pp.

Ward, R. D., Zemlak, T. S., Innes, B. H., Last, P. R. and Hebert, P. D. 2005. DNA barcoding Australia's fish species. Philos. Trans. R. Soc. Lond., B, Biol. Sci., 360(1462): 1847-1857. 